\title{
Genetic Variability and Correlation Studies for Yield and Yield Contributing Characters in Groundnut (Arachis hypogaea L.)
}

\author{
P. Gonya Nayak*, M. Venkataiah, P. Revathi and K. Sukumar
}

Division of Groundnut Research Scheme, Regional Agricultural Research Station, Professor Jayashankar Telangana State Agricultural University, Polasa - 505 529, Jagtial, Telangana, India

*Corresponding author

\section{A B S T R A C T}

\section{Keywords}

Groundnut, Genetic

variability, Heritability, Correlation

Article Info

Accepted:

04 July 2018

Available Online:

10 August 2018
Genetic parameters, variability, heritability and genetic advance were studied among 20 groundnut cultures rabi-2016-17 to study the variation and to identify traits of high heritability. The characters hundred kernel weight, hundred pod weight, dry pod yield and kernel yield had high GCV, heritability and GAM were found to be under the control of additive gene action, while the traits shelling percentage, sound mature kernel and final plant stand with moderate heritability and high genetic advance appeared to be under the predominant influence of additive gene action. Low GCV were recorded for days to fifty per cent flowering and duration of maturity. Correlation studies indicated that the characters, 100 seed weight $(\mathrm{g})$, hundred pod weight $(\mathrm{g})$, pod yield and kernel yield should be given major emphasis for the development of high yielding genotypes.

\section{Introduction}

Groundnut (Arachis hypogaea L.) is an important oilseed crop of tropical and subtropical regions of the world. It is the World's thirteenth most important food crop, the fourth most important source of edible oil and the third most important source of vegetable protein (Encyclopedia of Agricultural Science 1994). It is a primary source of edible oil and has high oil content (44 -50 per cent) and protein content (25 per cent). Groundnut oil contains 46 and 32 percent of monounsaturated fatty acids (MUFA) and polyunsaturated fatty acids (PUFA), respectively. India is the largest grower and second producer after China, the average area (4.19 million ha), production (5.62 million ton.) and productivity (1341 $\mathrm{kg} / \mathrm{ha}$ ) (Annual Reports of Groundnut Research Institute, Junagarh 2011-12). Variability in genotypes for yield and contributing traits form the basic factor while making selection. The presence and magnitude of genetic variability in a gene pool is the prerequisite of breeding programmes (Tiwari et al., 2011). Heritability of a trait is important in determining its response to selection. It was found out earlier that genetic improvement of plants for quantitative traits requires reliable estimate of heritability in order to plan an efficient breeding programme. Selection of 
superior parents with high heritability and genetic advance for various characters is an essential prerequisite for any yield improvement programme (Khan et al., 2008).

\section{Materials and Methods}

The experimental material consisted 20 genotypes of groundnut including checks (Kadiri-6 and JCG-88). The experiment was conducted in a randomized block design with three replications during rabi-2016-17 at Regional Agricultural Research Station, Jagtial. Each genotype was sown in 5 rows of $5 \mathrm{~m}$ length and $1.5 \mathrm{~m}$ width with a spacing of $30 \mathrm{~cm}$ between the rows and $10 \mathrm{~cm}$ within the plants.

Recommended package of practices were followed in raising the crop. Data was recorded on final plant stand, days to $50 \%$ flowering, days to maturity, shelling percentage, sound mature kernel, hundred pod weight $(\mathrm{g})$, hundred kernel weight $(\mathrm{g})$, kernel yield and pod yield/hectare. The mean of different characters were calculated on the basis of these individual data recorded for each character in each replication and subjected for analysis of variance (Fisher, 1936), coefficient of variation (Burton et al., 1952), heritability (Burton and Devane, 1953), genetic advance (Johnson et al., 1955).

\section{Results and Discussion}

The mean squares of various traits indicated that there were significant differences among the genotypes except final plant stand. Characters viz., days to $50 \%$ flowering, days to maturity, shelling percentage, sound mature kernel, hundred pod weight (g), hundred kernel weight (g), kernel yield and pod yield/hectare were presented in table 2. The genotypes, JCG-6736(2507kg/Ha) and JCG$6727(2631 \mathrm{Kg} / \mathrm{Ha})$ were found to be best genotypes for pod yield/ha.
The minimum differences in magnitude for the estimates of GCV and PCV for all the nine characters like final plant stand, days to $50 \%$ flowering, days to maturity, shelling percentage, sound mature kernel, hundred pod weight $(\mathrm{g})$, hundred kernel weight $(\mathrm{g})$, kernel yield and pod yield/hectare implied that the traits were mostly governed by genetic factors with little role of environment in the phenotypic expression of these characters (Manggoel et al., 2012). Hence phenotypic selection is rewarding for these traits.

The high genotypic coefficient of variation (GCV) was recorded for hundred kernel weight (15.3), hundred pod weight (11.9), dry pod yield per ha (11.2), and kernel yield per ha (10.2).

Similarly high PCV values were recorded for hundred kernel weight (17.5), hundred pod weight (13.2), dry pod yield (12.4) and kernel yield (11.9). Similar results were reported by Naazar et al., (2000), Kumar and Rajamani (2004), John et al., (2005), Khote et al., (2009) and Shinde et al., (2010).

Heritability plays an important role in deciding the stability and strategy for selection of a character.

In the present study high heritability was observed for traits viz., sound mature kernel (87.3), shelling per cent (87.2), dry pod yield per ha (81.3), hundred pod weight (81.0), hundred kernel weight (76.3) and kernel yield (72.8), while moderate heritability was recorded for days to maturity (55.9).

Similar results were obtained by Azad and Hamid (2000) and Parameshwarapp et al., (2005). It suggests high components of heritable portion of variation that can be exploited by breeders in the selection of superior genotypes on the basis of phenotypic performance (Table 1). 
Table.1 Per se performance of different yield and yield contributing characters in groundnut genotypes

\begin{tabular}{|c|c|c|c|c|c|c|c|c|c|c|}
\hline Genotype & FPS & DIF & DFF & DM & $\mathbf{S \%}$ & HKW & HPW & SMK & KY/ ha & DPY/ ha \\
\hline JCG-6707 & 191 & 28 & 31 & 109 & 71 & 23.3 & 69.0 & 89 & 1578 & 2230 \\
\hline JCG-6708 & 205 & 28 & 30 & 109 & 66 & 18.0 & 77.3 & 91 & 1564 & 2353 \\
\hline JCG-6709 & 189 & 27 & 29 & 110 & 69 & 23.0 & 56.7 & 92 & 1374 & 1991 \\
\hline JCG-6714 & 200 & 28 & 30 & 109 & 71 & 22.7 & 70.0 & 91 & 1387 & 1960 \\
\hline JCG-6722 & 191 & 27 & 29 & 110 & 66 & 27.7 & 64.7 & 87 & 1314 & 1991 \\
\hline JCG-6724 & 202 & 27 & 30 & 108 & 73 & 20.3 & 66.3 & 91 & 1390 & 1906 \\
\hline JCG-6727 & 202 & 27 & 29 & 107 & 55 & 22.3 & 60.7 & 75 & 1456 & 2631 \\
\hline JCG-6728 & 194 & 26 & 29 & 112 & 73 & 27.3 & 48.0 & 72 & 1729 & 2377 \\
\hline JCG-6736 & 197 & 27 & 29 & 111 & 56 & 28.3 & 74.3 & 89 & 1413 & 2508 \\
\hline JCG-6737 & 183 & 27 & 29 & 109 & 72 & 23.0 & 71.0 & 85 & 1263 & 1759 \\
\hline JCG-6738 & 188 & 27 & 30 & 108 & 72 & 22.0 & 80.7 & 89 & 1765 & 2446 \\
\hline JCG-6739 & 193 & 27 & 30 & 109 & 69 & 27.0 & 68.0 & 91 & 1526 & 2207 \\
\hline JCG-6740 & 175 & 27 & 29 & 108 & 71 & 18.7 & 79.7 & 92 & 1348 & 1898 \\
\hline JCG-6741 & 190 & 27 & 30 & 109 & 66 & 19.3 & 69.7 & 91 & 1271 & 1921 \\
\hline JCG-6742 & 197 & 27 & 29 & 109 & 68 & 28.7 & 81.3 & 88 & 1327 & 1968 \\
\hline JCG-6743 & 171 & 27 & 30 & 110 & 71 & 27.0 & 76.0 & 93 & 1584 & 2230 \\
\hline JCG-6745 & 184 & 27 & 29 & 109 & 65 & 17.3 & 81.0 & 90 & 1225 & 1883 \\
\hline JCG-6746 & 194 & 29 & 31 & 108 & 57 & 27.3 & 77.3 & 88 & 1250 & 2207 \\
\hline Kadiri-6 & 184 & 28 & 30 & 105 & 63 & 27.7 & 69.7 & 86 & 1570 & 2292 \\
\hline JCG-88 & 179 & 28 & 30 & 108 & 67 & 20.3 & 66.3 & 79 & 1439 & 2137 \\
\hline Mean & 190 & 27 & 30 & 109 & 67 & 23.6 & 70.4 & 87 & 1439 & 2155 \\
\hline C.V. & 6.1 & 3.1 & 3.4 & 1.0 & 3.0 & 8.5 & 5.7 & 2.4 & 6.2 & 5.4 \\
\hline C.D. $5 \%$ & 19.2 & - & - & 1.7 & 3.4 & 3.3 & 6.7 & 3.5 & 148.1 & 191.4 \\
\hline Range Lowest & 170.7 & 26.3 & 28.7 & 105.0 & 55.3 & 17.3 & 48.0 & 71.7 & 1224.6 & 1759.3 \\
\hline Range Highest & 204.7 & 28.7 & 31.3 & 111.7 & 73.0 & 28.7 & 81.3 & 92.7 & 1765.0 & 2631.2 \\
\hline
\end{tabular}

FPS $=$ Final plant stand, DFF= Duration of fifty per cent flowering, DM= Duration of maturity, S\%= Shelling percentage, HKW= Hundred kernel weight, HPW=Hundred pod weight, SMK= Sound mature kernel, DPY= Dry pod yield and KY= Kernel yield.

Table.2 Analysis of variance (Mean Squares) for yield and yield components in Groundnut

\begin{tabular}{|c|c|c|c|c|c|c|c|c|c|c|c|}
\hline Source of variation & Df & FPS & DIF & DFF & DM & $\mathrm{S} \%$ & HKW & HPW & SMK & Kernel Yield/ Ha & DPY \\
\hline Replications & 2 & 181.7 & $5.81 * *$ & $9.65^{* *}$ & $16.46 * *$ & $151.71 * *$ & $42.11 * *$ & 10.31 & $37.61 * *$ & $0.012 * *$ & 0.0001 \\
\hline Treatments & 19 & 251.1 & 0.89 & 1.35 & $5.26 * *$ & $88.86 * *$ & $43.02 * *$ & $225.23 * *$ & $99.44 * *$ & $0.013 * *$ & $0.035 * *$ \\
\hline Error & 38 & 135.6 & 0.69 & 1.01 & 1.09 & 4.15 & 4.02 & 16.31 & 4.58 & 0.001 & 0.002 \\
\hline
\end{tabular}


Table.3 Phenotypic and genotypic correlation coefficients among yield and other parameters in groundnut genotypes

\begin{tabular}{|c|c|c|c|c|c|c|c|c|c|c|c|}
\hline Character & & FPS & DIF & DFF & DM & S\% & HKW & HPW & SMK & KY/ha & DPY/ha \\
\hline \multirow[t]{2}{*}{ FPS } & $\mathbf{P}$ & 1.000 & -0.022 & -0.065 & 0.1281 & -0.1879 & -0.0034 & -0.157 & -0.139 & 0.012 & 0.152 \\
\hline & G & 1.000 & $0.951^{* *}$ & 0.395 & 0.053 & $-0.486^{* *}$ & 0.036 & $-0.365 * *$ & -0.244 & 0.019 & 0.205 \\
\hline \multirow[t]{2}{*}{ DIF } & $\mathbf{P}$ & & 1.000 & 0.780 ** & -0.204 & -0.172 & 0.092 & 0.102 & 0.119 & 0.007 & 0.116 \\
\hline & G & & 1.000 & $1.057 * *$ & -0.758 & $-0.782 * *$ & -0.025 & $0.396 * *$ & 0.217 & -0.208 & -0.266 \\
\hline \multirow[t]{2}{*}{ DFF } & $\mathbf{P}$ & & & 1.000 & -0.150 & -0.0036 & -0.060 & 0.101 & 0.093 & 0.133 & 0.101 \\
\hline & G & & & 1.000 & $-0.611^{* *}$ & -0.206 & -0.191 & $0.470 * *$ & 0.184 & 0.163 & 0.200 \\
\hline \multirow[t]{2}{*}{ DM } & $\mathbf{P}$ & & & & 1.000 & 0.1648 & 0.124 & -0.249 & -0.047 & 0.076 & -0.059 \\
\hline & G & & & & 1.000 & 0.196 & 0.201 & $-0.311 * *$ & -0.076 & 0.075 & 0.087 \\
\hline \multirow[t]{2}{*}{$5 \%$} & $\mathbf{P}$ & & & & & 1.000 & -0.211 & -0.057 & 0.199 & $0.293^{*}$ & $-0.457 * *$ \\
\hline & G & & & & & 1.000 & -0.239 & -0.114 & 0.203 & $0.284^{*}$ & 0.230 \\
\hline \multirow[t]{2}{*}{ HKW } & $\mathbf{P}$ & & & & & & 1.000 & -0.206 & -0.157 & 0.128 & $0.275^{*}$ \\
\hline & G & & & & & & 1.000 & -0.172 & -0.192 & 0.225 & -0.176 \\
\hline \multirow[t]{2}{*}{ HPW } & $\mathbf{P}$ & & & & & & & 1.000 & $0.561 * *$ & -0.208 & -0.165 \\
\hline & G & & & & & & & 1.000 & $0.643 * *$ & $-0.254^{*}$ & 0.342 \\
\hline \multirow[t]{2}{*}{ SMK } & $\mathbf{P}$ & & & & & & & & 1.0000 & -0.212 & $-0.359 * *$ \\
\hline & G & & & & & & & & 1.000 & $-0.317 *$ & 0.506 \\
\hline \multirow[t]{2}{*}{ KY/Ha } & $\mathbf{P}$ & & & & & & & & & 1.000 & $0.711 * *$ \\
\hline & G & & & & & & & & & 1.000 & 0.186 \\
\hline \multirow[t]{3}{*}{ DPY/Ha } & $\mathbf{P}$ & & & & & & & & & & 1.000 \\
\hline & G & \multicolumn{2}{|c|}{ Significance levels } & 0.05 & 0.01 & & & & & & 1.000 \\
\hline & & If cor & & 0.254 & 0.330 & & & & & & \\
\hline
\end{tabular}

$\mathrm{P}=$ Phenotypic correlation coefficients, $\mathrm{G}=$ Genotypic correlation coefficients * $=$ Significant at $\mathrm{P}<0.05$, ** $=$ Significant at $\mathrm{P}<0.0$

Table.4 Components of genetic variability for ten characters in groundnut genotypes

\begin{tabular}{|c|c|c|c|c|c|c|}
\hline \multirow[t]{2}{*}{ Character } & \multicolumn{2}{|c|}{ Range } & \multirow[t]{2}{*}{ GCV } & \multirow[t]{2}{*}{ PCV } & \multirow[t]{2}{*}{$h^{2}($ Broad Sense $)$} & \multirow[t]{2}{*}{ GAM (at 5\%) } \\
\hline & Min & Max & & & & \\
\hline Final plant stand & 170.1 & 204.7 & 3.3 & 6.9 & 22.1 & 3.2 \\
\hline Days to initial flowering & 26.6 & 28.7 & 1.0 & 3.2 & 8.8 & 0.6 \\
\hline Days to $50 \%$ flowering & 28.7 & 31.3 & 1.1 & 3.6 & 9.8 & 0.7 \\
\hline Days to maturity & 105.0 & 111.7 & 1.1 & 1.5 & 55.9 & 1.7 \\
\hline Shelling\% & 55.3 & 73.0 & 7.9 & 8.5 & 87.2 & 15.2 \\
\hline Hundred kernel weight & 17.3 & 28.7 & 15.3 & 17.5 & 76.3 & 27.5 \\
\hline Hundred pod weight & 48.0 & 81.3 & 11.9 & 13.2 & 81.0 & 22.0 \\
\hline Sound mature kernel & 71.7 & 92.7 & 6.4 & 6.9 & 87.3 & 12.4 \\
\hline Dry Pod Yield/ Ha & 1759.3 & 2631.2 & 11.2 & 12.4 & 81.3 & 20.8 \\
\hline Kernel Yield/ Ha & 1224.6 & 1765.0 & 10.2 & 11.9 & 72.8 & 17.9 \\
\hline
\end{tabular}


Maximum genetic advance was recorded for hundred kernel weight (27.5), Hundred pod weight (22.0) and dry pod yield (20.8). Moderate amount of genetic advance was recorded for kernel yield (17.9), Sound mature kernel (12.4) and shelling percentage (15.2). In the present study hundred kernel weight, hundred pod weight, shelling percentage, dry pod yield per ha and kernel yield showed high genetic advance along with high heritability, genotypic and phenotypic coefficient of variation which suggested that these characters can be considered as favorable attributes for the improvement through selection and this may be due to additive gene action.

At phenotypic level pod yield showed significant positive correlation with hundred kernel weight (0.275), kernel yield (0.711) and negative correlation for shelling per cent $(-0.457)$ and sound mature kernel (-0.359). Kernel yield showed significant positive correlation with shelling per cent (0.293) while, sound mature kernel showed significant positive correlation with hundred pod weight (0.561). Days to fifty per cent flowering showed significant positive correlation with duration of initial flowering (0.780) (Table 3).

At genotypic level Kernel yield per ha recorded highly significant positive correlation with shelling percentage $(0.284)$ and negative correlation with hundred pod weight (-0.254) and sound mature kernel (0.317). Sound mature kernel showed significant positive correlation with hundred pod weight (0.643). Hundred pod weight recorded highly significant positive correlation with duration of initial flowering (0.396), fifty per cent flowering (0.470) and negative correlation with final plant stand ($0.365)$ and duration of maturity (-0.311). Shelling per cent showed negative correlation with final plant stand (-0.486), duration of initial flowering (-0.782) and duration of maturity recorded negative correlation with duration of fifty percent flowering (-0.611). Duration of initial flowering showed positive correlation with final plant stand (0.951) (Table 4).

Eighteen genotypes were studied for genetic variability and correlation studies, among these two genotypes were recorded highest per se values for yield viz., JCG-6727 (2631 $\mathrm{kg} / \mathrm{ha}$ ) and JCG-6736 (2508 kg/ha). Whereas six entries recorded more than 70 per cent of shelling out turn. These genotypes can be used as parental material for crossing programme to improve the specific yield attributing characters in groundnut.

\section{References}

Annual Reports of Groundnut Research Institute, Junagarh 2011-12. Page no. 175

Burton, G. W. (1952). Quantitative inheritance in grasses. Proceedings 6th International Grassland Congresses1: 227-283.

Burton, G. W. and Devane, E. H. (1953). Estimating heritability in tall fascue (Restuca arundian) from replicated clonal material. Agronomy Journal, 45 (1): $478-481$.

Encyclopedia of Agricultural Science (1994). Groundnut (Arachis hypogaea L.). Academic press. 3: 112.

Fisher, R. A. (1936). The correlation between relative on the supposition of genotypes grown in Kumaun Himalaya, Indian Journal of Genetics and plant breeding, 66 (1): 37-38.

Johnson, H. W, Robinson, H. F. and Comstock, R. E. (1955). Genotypic and phenotypic correlation in soybean and their implications in selection. Agronomy Journal, 47: 477- 483. 
Khote, A. C, Bendale, V. W, Bhave, S. G. and Patil, P. P. (2009). Genetic variability, heritability and genetic advance in some exotic genotypes of groundnut (Arachis hypogaea L.). Crop Research (Hisar), 37 (1/3): 186-191.

Kumar, C. V. S. and Rajamani, S. (2004). Genetic variability and heritability in groundnut (Arachis hypogea L.). Progressive Agriculture, 4 (1): 69-70.

Naazar Ali, Malik, S. N. and Khurram Bashir Mirza, M. Y. (2000). Genetic variability, heritability and correlation studies in groundnut. Sarhad Journal of Agriculture, 16 (5): 533-536.
Shinde, P. P, Khanpara, M. D, Vachhani, J. H, Jivani, L. L. and Kachhadia, V. H. (2010). Genetic variability in Virginia bunch groundnut (Arachis hypogaea L.). Plant Archives, 10 (2): 703-706.

Tiwari, R, Suresh, B. G, Mishra, V. K, Kumar A. and Kumar A. (2011). Genetic variability and character association in direct seeded upland rice (Oryza sativa). mitogen-activated protein kinase kinases Publication 29 (4A): 21322135.

\section{How to cite this article:}

Gonya Nayak, P., M. Venkataiah, P. Revathi and Sukumar, K. 2018. Genetic Variability and Correlation Studies for Yield and Yield Contributing Characters in Groundnut (Arachis hypogaea L.). Int.J.Curr.Microbiol.App.Sci. 7(08): 151-156.

doi: https://doi.org/10.20546/ijcmas.2018.708.019 